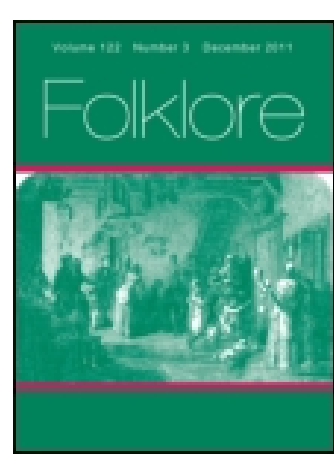

Folklore

\title{
History and Tradition
}

\section{Kate Lee}

To cite this article: Kate Lee (1903) History and Tradition, Folklore, 14:2, 178-179, DOI:

10.1080/0015587X.1903.9719353

To link to this article: http://dx.doi.org/10.1080/0015587X.1903.9719353

曲 Published online: 06 Feb 2012.

Submit your article to this journal $\pi$

Џll Article views: 1

Q View related articles $\longleftarrow$ 


\section{History and Tradition.}

A few weeks ago I took down some conversations from three old people about the Civil War. These people live in a straggling hamlet between Bradford-on-Avon and Bath, called Farleigh Wick. The land stands about 500 feet above the river Avon.

I first began talking to Mr. Sumsion about the whereabouts of the old main road, traces of which are to be seen; and he pointed out a portion of it running close by his very cottage-he remembered it well.

"'Twere a different sort of road to what is made now," he said. "It went up through Farleigh Wick just as 'tis now, crossed over to Shoots Lane, and went right down the steep valley' over the ford to Bath; 'twas terrible when they drov' the cattle down there."

"What was Shoots lane?" said I.

"Where they fought," said he.

"When was the fighting?" I asked.

"Oh 1 'twas when they fought to help keep the French awayI only knowed about it from my great-grandfather. He talked of it. Soldiers, hundreds of 'em, passed up here and was killed there."

Mrs. Sumsion chimed in that "Shoots Iane ran with blood."

Old Mrs. Deverell in the village remembered more.

"They was fighting all day," said she; "and the king was sitting having his dinner in Claverton Manor when a cannon ball burst close to him. It was a wonder he wasn't killed "- her grandmother knew a lot about it-."'twas common talk here," she said.

My last informant was smoking a płpe in the immediate locality of Shoots lane.

"Yes, this is the place," he said, "and the walls have never been touched. You can see the holes in them made by the guns."

We walked down Shoots Lane--a muddy narrow farm track, with ruinous walls covered with ivy and other growth. There were great gaps here and there, and thick ivy growing in between.

"They used to pick up guns and such-like when I was a lad, but there's nothing left now."

The lane looks right over Claverton Manor. 
Mr. Sweetland said his father talked of the old war, and the soldiers marching after the battle to King's Down.

The Squire of Warleigh Manor showed me two cannon-balls found in Claverton Manor. The villagers told me these little stories as if it had all happened a few years ago.

Ortober, 1902.

KATE LEE.

[These traditions probably refer to the skirmish of 3 rd July, I643. The Parliamentary forces under Waller held Bath, and were attacked by the Royalists under Hopton, who had marched from Chewton, north of the Mendips, eastwards to Frome, and then northwards by the valley of the Avon, on their way to join the king. On the 3 rd July they "drew a small body of the enemy out of Monkton Farleigh, on the high ground to the north of the river, but Waller's main army was on the other side of the valley, under Claverton Down, and they neither dared to cross the river in the face of the enemy, nor to pursue their way to Bath, leaving him in the rear." They therefore pushed on through Monkton Farleigh and worked round to the north-west of Bath, where the indecisive battle of Lansdown was fought on July $5^{\text {th. }}$ (Gardiner's History of the Civil War, i., I98.) It does not appear that the King was present. Collinson's History of Somerset ( 1791 ) says of Claverton: "The manor-house is a noble old building adjoining to the Church. . ... In the Civil Wars temp. Car. I., when Sir William Basset, Sir Edward Hungerford, and other gentlemen, were dining in this house, a cannon ball, directed from the hill opposite, pierced through the outer wall of the hall, and passing over the table at which they sat, lodged in the breast wall of the chimney without doing further mischief," (vol. i., p. 146),-..-Es.]

Death and the Herb Thyme.

In William Thornber's History of Blackpool, ${ }^{8} 837$, p. 38 , it is said that the "boggart" of Staining Hall, near the town, was "the wandering ghost of a Scotchman, murdered near a tree, which has since recorded the deed by perfuming the ground around with 